\title{
Absorption, scattering and single scattering albedo of aerosols obtained from in situ measurements in the subarctic coastal region of Norway
}

\author{
E. Montilla ${ }^{1, *}$, S. Mogo ${ }^{1,2}$, V. Cachorro ${ }^{1}$, J. Lopez ${ }^{1,3}$, and A. de Frutos ${ }^{1}$ \\ ${ }^{1}$ Universidad de Valladolid, Grupo de Óptica Atmosférica, Spain \\ ${ }^{2}$ Universidade da Beira Interior, Faculdade de Ciências, Covilhã, Portugal \\ ${ }^{3}$ Instituto Nacional de Técnica Aeroespacial, Mazagón, Huelva, Spain \\ *now at: Universidad de Concepción, Center for Optics and Photonics, Chile
}

Received: 2 January 2011 - Accepted: 13 January 2011 - Published: 20 January 2011

Correspondence to: S. Mogo (sipmogo@gmail.com)

Published by Copernicus Publications on behalf of the European Geosciences Union.

\begin{abstract}
In situ measurements of aerosol optical properties were made in summer 2008 at the ALOMAR station facility $\left(69^{\circ} 16 \mathrm{~N}, 16^{\circ} 00 \mathrm{E}\right)$, located at a rural site in the North of the island of Andøya (Vesterålen archipelago), about $300 \mathrm{~km}$ north of the Arctic Circle. The 5 extended three months campaign was part of the POLAR-CAT Project of the International Polar Year (IPY-2007-2008), and its goal was to characterize the aerosols of this sub-Arctic area which frequently transporte to the Arctic region. The ambient lightscattering coefficient, $\sigma_{s}(550 \mathrm{~nm})$, at ALOMAR had a hourly mean value of $5.412 \mathrm{Mm}^{-1}$ $\left(\mathrm{StD}=3.545 \mathrm{Mm}^{-1}\right)$ and the light-absorption coefficient, $\sigma_{\mathrm{a}}(550 \mathrm{~nm})$, had an hourly 10 mean value of $0.400 \mathrm{Mm}^{-1}\left(\mathrm{StD}=0.273 \mathrm{Mm}^{-1}\right)$. The scattering/absorption Ångström exponents, $\alpha_{\mathrm{s}, \mathrm{a}}$, are used for detailed analysis of the variations of the spectral shape of $\sigma_{\mathrm{s}, \mathrm{a}}$. The single scattering albedo, $\omega_{0}$, ranges from 0.622 to 0.985 (mean $=0.913$, $\mathrm{StD}=0.052)$ and the relation of this property to the absorption/scattering coefficients and the Ångström exponents is presented. The relationships between all the parame-

15 ters analyzed, mainly those related to the single scattering albedo, allow us to describe the local atmosphere as extremely clean.
\end{abstract}

\section{Introduction}

The net effect of aerosols on global climate change is uncertain since the effect of particles can be to cool or to warm, depending on their optical properties. The reduction 20 in the intensity of a direct solar beam during its propagation through the atmosphere is determined by absorption and scattering processes. The aerosol single scattering albedo, $\omega_{0}$, is defined as the fraction of the aerosol light scattering over the extinction:

$\omega_{0}=\frac{\sigma_{\mathrm{s}}}{\sigma_{\mathrm{s}}+\sigma_{\mathrm{a}}}$,

where $\sigma_{\mathrm{s}}$ and $\sigma_{\mathrm{a}}$ are the aerosol scattering and absorption coefficients, respectively.

$25 \omega_{0}$ is one of the most relevant optical properties of aerosols, since their direct radiative 
effect is very sensitive to it. Those optical properties of aerosol particles suspended in the atmosphere show, in general, a great spatial and temporal variability and are determined by their chemical composition, size, shape, concentration and mixing state (Kokhanovsky, 2008).

5 Sulfate and nitrate aerosols from anthropogenic sources, are considered the primary particles responsible for net cooling. They scatter solar radiation and are effective as cloud condensation nuclei affecting the lifetime of clouds, the hydrological cycle and resulting in a negative radiative forcing that leads to a cooling of the Earth's surface. To some extent, they are thought to counteract global warming caused by greenhouse 10 gases such as carbon dioxide (Boucher and Haywood, 2001). On the other hand, light-absorbing particles, mainly formed by black carbon produced by incomplete combustion of carbonaceous fuels, are effective absorbers of solar radiation and have, therefore, the opposite effect i.e. they warm the atmosphere. Absorption of solar radiation by aerosols causes heating of the lower troposphere, which may lead to altered 15 vertical stability, with implications for the hydrological cycle (Ramanathan et al., 2001).

In addition, deposition of light-absorbing particles onto snow and ice results in a reduction of the surface albedo, which in turn affects the snow pack and the Earth's albedo (Law and Stohl, 2007; IPCC, 2007). Clarke and Noone (1985) found that the snow albedo is reduced by $1-3 \%$ in fresh snow and by a factor of 3 as the snow 20 ages and the light absorbing particles become more concentrated. The Arctic summer provides an excellant opportunity to study aerosols in regions where there are few sources of natural particles and limited influence of man-made sources.

The data retrieved from satellites are limited to clear sky conditions and are mainly valid over dark targets; few satellites retrieve data valid over bright land and snow/ice surfaces. Also, aerosol optical properties are much more variable at the surface than at the top of the atmosphere making them much more difficult to estimate ( $\mathrm{Li}$ et al., 2007). While columnar aerosol properties have already been studied (Toledano et al., 2006), as far as we know, no work has been reported on surface measurements of these important optical aerosol properties in the area of our study.

2163

This study was carried out within the framework of a larger intensive aerosol characterization campaign conducted in northern Norway at a remote subarctic site in summer 2007 and 2008. The main goal of the campaign was to acquire a comprehensive physical and chemical characterization of local aerosol. It was part of the participation 5 of the Atmospheric Optics Group of Valladolid University to the International Polar Year through the POLAR-CAT project, led by the Norwegian Institute for Air Research. Several instruments for aerosol characterization were employed simultaneously: an ultrafine condensation particle counter (UCPC), a scanning mobility particle sizer (SMPS) and an aerodynamic particle sizer (APS) for numerical size particle distribution in ultra-

10 fine, fine and coarse fractions respectively; a cascade impactor having four stages for independent absorption coefficient determination with an integrating sphere technique; a diffraction grating spectroradiometer (ASD) was used for global irradiance measurement and a CIMEL photometer for columnar optical aerosol properties. Finally, the aerosol radiative properties were examined using a particle soot absorption photome15 ter (PSAP) and a nephelometer.

In the present work only results from aerosol absorption and scattering measurements are presented. Our primary goal was to investigate light absorption/scattering coefficients and their Ångström exponents, $\alpha_{\mathrm{a}}, \alpha_{\mathrm{s}}$. The determination of optical parameters as a function of wavelength is useful to distinguish between different aerosol

20 types. For example, Dubovik et al. (2002) found that for urban-industrial aerosols and for biomass burning the $\omega_{0}$ decreases with increasing wavelength, while for desert dust, $\omega_{0}$ increases with increasing wavelength. Rosen et al. (1979) measured $\alpha_{\mathrm{a}}=1.0$ for urban aerosol and Bond (2001) studied the spectral dependence of visible light absorption by carbonaceous particles emitted from coal combustion and found strong 25 spectral dependency, $1.0<\alpha_{\mathrm{a}}<2.9$. 


\section{Methods}

\subsection{Site description}

The ALOMAR (Arctic Lidar Observatory for Middle Atmosphere Research) station is located on Andøya island close to Andenes town ( $69^{\circ} 16 \mathrm{~N}, 16^{\circ} 00 \mathrm{E}, 380 \mathrm{~m}$ a.s.l.), on

5 the Atlantic coast of Norway about $300 \mathrm{~km}$ north of the Arctic Circle, Fig. 1. The facility is managed by the Andøya Rocket Range and the site is very suitable for tropospheric measurements due to the absence of large regional pollution sources. From the end of May to the end of July the sun is $24 \mathrm{~h}$ above the horizon, with a maximum elevation during the solstice of $42^{\circ}$ at noon and $2^{\circ}$ at midnight. The climate is strongly influenced by

10 the Gulf Stream, which provides mild temperatures during the entire year, with average temperatures of $-2^{\circ} \mathrm{C}$ in January and $11^{\circ} \mathrm{C}$ in July. Rapid variations of temperature can occur in summer months, from $4^{\circ}$ to $30^{\circ} \mathrm{C}$. Further details on the measurement station can be found on Skatteboe (1996) and Toledano et al. (2006).

\subsection{Instrumentation}

15 Aerosol samples were obtained from a stainless steel inlet protected with a rain cap and a metal screen designed to keep away insects. The inlet of the sampling line is about $2 \mathrm{~m}$ above the roof of the measurement station building, about $7 \mathrm{~m}$ above the ground. The cut off diameter of the inlet nozzle and sample transport line was about $10 \mu \mathrm{m}$. The sample air is heated when necessary to achieve a low relative humidity

20 of $40 \%$ prior to entering the instruments. Airflow through the sampling line is divided into several separate flows and is directed to individual instruments. The working flow to each instrument was controlled once a day using an electronic bubble flowmeter (Gilibrator system, Gilian).

The light absorption coefficients were measured at three wavelengths (470, 522 and $25660 \mathrm{~nm}$ ) with a particle soot absorption photometer (PSAP, Radiance Research) working with flow set to $1.5 \mathrm{Imin}^{-1}$. The instrument uses a filter-based technique in which

2165

aerosols are continuously deposited onto a glass fiber filter at a known flow rate. The change in the transmitted light is related to the optical absorption coefficient using Beer's law. The instrument is an improved version of the integrating plate method (Lin et al., 1973) and is described in detail by Bond et al. (1999) and Virkkula et al. (2005).

The scattering and backscattering coefficients were measured at three wavelengths (450, 550 and $700 \mathrm{~nm}$ ) with an integrating nephelometer (model 3563, TSI) working with a flow rate of $46 \mathrm{Imin}^{-1}$. The instrument is described in detail by Anderson et al. (1996) and Anderson and Ogren (1998). Calibration is carried out twice per month by using $\mathrm{CO}_{2}$ as high span gas and filtered air as low span gas. The averaging time was

10 set to $1 \mathrm{~min}$. The zero signal was measured once per hour. For the 1-min averages applied here, the detection limits for scattering coefficients are $0.65,0.25,0.38 \mathrm{Mm}^{-1}$ for 450, 550 and $700 \mathrm{~nm}$, respectively (Anderson et al., 1996).

\subsection{Data processing}

The response of the PSAP depends on the loading of particles on the filter, on the 15 amount of light scattered by the particles, on the flow rate and on the spot size (Bond et al., 1999; Virkkula et al., 2005). The data were corrected for these dependencies according to the procedure described by Bond et al. (1999). The averaging time was $60 \mathrm{~s}$ and the filter was replaced whenever the amount of transmitted light achieved $70 \%$ of the initial intensity. As the algorithms presented by Bond et al. (1999) and

20 Virkkula et al. (2005) agreed well for higher $\omega_{0}$ and smaller $\sigma_{a}$, and no other values of $\sigma_{\mathrm{a}}>6 \mathrm{Mm}^{-1}$ have been observed at ALOMAR during the measurements, there is no need to apply the correction procedure proposed by Virkkula et al. (2005).

The corrected aerosol absorption coefficients at 470,522 and $660 \mathrm{~nm}$ were extrapolated to the working wavelengths of the nephelometer, 450, 550 and $700 \mathrm{~nm}$.

25 We prefer not to present backscattering as their values lie below the error threshold.

For investigating the wavelength dependence of $\sigma_{\mathrm{a}, \mathrm{s}}$, we calculated the absorption/scattering Ångström exponent. This parameter is commonly used for a more 
detailed analysis of the variations of the spectral shape of $\sigma_{\mathrm{a}, \mathrm{s}}$ and is defined as the negative slope of the logarithm of absorption coefficient as a function of wavelength and is given by:

$\sigma_{\mathrm{a}, \mathrm{s}}=K \lambda^{-\alpha_{\mathrm{a}, \mathrm{s}}}$.

5 In practice, we calculated $\alpha_{\mathrm{a}, \mathrm{s}\left(\lambda_{1}, \lambda_{2}, \ldots, \lambda_{n}\right)}$ for more than two wavelengths through the logarithmic fit of Eq. (2) and we calculated $\alpha_{\mathrm{a}, \mathrm{s}\left(\lambda_{1}, \lambda_{2}\right)}$ for a pair of wavelengths, $\lambda_{1}, \lambda_{2}$, according to the following simplified formula:

$\alpha_{\mathrm{a}, \mathrm{s}}=-\frac{\log \left(\sigma_{\mathrm{a}, \mathrm{s}\left(\lambda_{2}\right)} / \sigma_{\mathrm{a}, \mathrm{s}\left(\lambda_{1}\right)}\right)}{\log \left(\lambda_{2} / \lambda_{1}\right)}$.

Absorption and scattering data are available from 13 June to 26 August 2008. The

10 statistical data are calculated based on the hourly averages, which seems reasonable given the low values observed. The hourly averages were preferred to the daily averages since they are more sensitive to local effects, while the daily averages are more useful to identify external long range effects.

\section{Results and discussion}

\section{$15 \quad 3.1$ Temporal variations in aerosol properties}

The aerosols sampled on ALOMAR during the 2008 summer campaign were representative of an extremely clean area. During our observations, hourly mean $\sigma_{\mathrm{s}}$ at $450 \mathrm{~nm}$, $550 \mathrm{~nm}$ and $700 \mathrm{~nm}$ ranged from 0.289 to $31.236 \mathrm{Mm}^{-1}, 0.254$ to $23.209 \mathrm{Mm}^{-1}$ and 0.193 to $18.950 \mathrm{Mm}^{-1}$ (average $7.309,5.412$ and $4.083 \mathrm{Mm}^{-1}$ and standard deviation

$204.794,3.545$ and $2.841 \mathrm{Mm}^{-1}$ ), respectively. The hourly mean values of $\sigma_{\mathrm{a}}$ at $450 \mathrm{~nm}$, $550 \mathrm{~nm}$ and $700 \mathrm{~nm}$ ranged from 0.135 to $2.715 \mathrm{Mm}^{-1}, 0.130$ to $2.281 \mathrm{Mm}^{-1}$ and 0.119 to $1.917 \mathrm{Mm}^{-1}$ (average $0.448,0.400$ and 0.358 and standard deviation $0.329,0.273$ and $0.226 \mathrm{Mm}^{-1}$ ), respectively. For both parameters the median value is lower than 2167

the mean. While the value of $\sigma_{\mathrm{s}}$ varies widely, more than two orders of magnitude, the value of $\sigma_{\mathrm{a}}$ remains more stable. The statistics on $\sigma_{\mathrm{s}}$ and $\sigma_{\mathrm{a}}$ values is presented in Table 1 and a time series representing over 70 days of measurement is shown in Fig. 2.

1166 hourly means are available for $\sigma_{\mathrm{s}}$ and 1046 for $\sigma_{\mathrm{a}}$, which allowed for the calculation of 883 hourly values of $\omega_{0}$. The frequency histogram of $\sigma_{\mathrm{s}}, \sigma_{\mathrm{a}}$ and $\omega_{0}$ at $550 \mathrm{~nm}$, shown in Fig. 3, presents only one frequency mode, centered at $3 \mathrm{Mm}^{-1}, 0.3 \mathrm{Mm}^{-1}$ and 0.95 , respectively for each parameter. Though the magnitude of $\sigma_{\mathrm{s}}$ and $\sigma_{\mathrm{a}}$ depend on many factors, our results were compared with literature values of some other areas 10 and Table 1 suggests that the magnitude of aerosol scattering/absorption coefficients in ALOMAR were comparable to those in other polar regions, such as those presented by Delene and Ogren (2002) and Quinn et al. (2007) at Barrow, or Aaltonen et al. (2006) at Pallas.

Correspondingly, the hourly mean values of the $\omega_{0}$ parameter measured at ALOMAR 15 were found to present an average value of $0.928,0.913$ and 0.893 for $450 \mathrm{~nm}, 550 \mathrm{~nm}$ and $700 \mathrm{~nm}$, respectively; ranging from 0.601 to $0.986,0.622$ to 0.985 and 0.496 to 0.986 , see Fig. 2 and Table 1. Nonetheless, the lower value registered was 0.622 $(450 \mathrm{~nm})$, in fact, it was observed to vary mainly between 0.8 and 0.985 as can be seen in Fig. 2 and confirmed by the value of the median, $0.923(450 \mathrm{~nm})$. See also

20 Fig. 3. These values are in the range presented for polar regions by several authors and compiled by Tomasi et al. (2007).

The spectral series of $\sigma_{\mathrm{s}}$ and $\sigma_{\mathrm{a}}$ measured were examined to derive the corresponding values of the scattering and absorption Ångström exponents following the best fit procedure based on Eq. (2). The Ångström exponent calculated for the $450 \mathrm{~nm} / 700 \mathrm{~nm}$

25 wavelength pair was found to range between 0.196 and 3.069 for scattering and between 0.008 and 0.969 for absorption. Statistical properties of the hourly mean values of the calculated parameters are presented in Table 1 and show mean values of 1.368 and 0.403 , respectively. In both cases the median value is lower than the mean. The standard deviations are 0.613 and 0.205 , respectively. Figure $4 a$ shows the hourly 
mean Ångström exponent values for the $450 \mathrm{~nm} / 700 \mathrm{~nm}$ wavelength pair covering the whole measurement period.

The frequency histogram of $\alpha_{\mathrm{s}}$ and $\alpha_{\mathrm{a}}$ are shown in Fig. $4 \mathrm{~b}, \mathrm{c}$. The histogram for $\alpha_{\mathrm{a}}$ presents only one frequency mode, centered at 0.35 , whereas the histogram for

${ }_{5} \alpha_{\mathrm{s}}$ presents two modes, centered at 0.7 and 1.9 , respectively. While the absorption Ångström exponent is in the range presented for other polar regions (Tomasi et al., 2007; Aaltonen et al., 2006), the scattering Ångström exponent presents some higher values more typical of sites affected by urban or continental pollution (Vrekoussis et al., 2005).

10 We also analyzed the spectral dependence of the single-scattering albedo, since this parameter, $\alpha_{\omega_{0}}$, is known to be very sensitive to the composition of the particles. For the $450 \mathrm{~nm} / 700 \mathrm{~nm}$ wavelength pair, $\alpha_{\omega_{0}}$ was found to range between -0.112 and 0.949 , mean value of 0.091 and standard deviation of 0.088 . Therefore, the high standard deviation of this parameter within its range of values indicates that a large variety of

15 aerosol types are present at ALOMAR during summer. The observed negative values are due to desert aerosol air masses that reach the ALOMAR station. These are rare and usually weak short duration episodes as the desert aerosol has to travel across Europe before reaching ALOMAR station. However, one or two events, 1 to 2 days long, have been observed every summer (Rodríguez, 2009).

\section{$20 \quad 3.2$ Relationships between the aerosol parameters}

In Fig. 5a, c we present the correlation between the scattering/absorption in the different channels. The relation between channels describes the proportion of the measurements for different wavelengths and each pair of measurements should obey the Eq. (2). In this way, the slope of the linear fit for each correlation is the respective

25 Ångström exponent. For absorption coefficients one line is enough to correlate the different channels but for scattering we observe two lines with different slopes. The slopes depend on the particle size, therefore apparently these two lines represent different aerosol types and the Ångström exponent can be used to help in identifying 2169

those aerosol types. The line with smaller slope is due to larger particles, probably maritime aerosols, while the line with higher slope is due to smaller particles, maybe continental aerosol.

Also in Fig. 5b, d, we present the relation between scattering/absorption coefficients 5 and the respective Ångström exponents. The Ångström exponents were calculated for the pairs of wavelengths $450 \mathrm{~nm} / 550 \mathrm{~nm}\left(\alpha_{\mathrm{a}, \mathrm{s}(450-550)}\right), 550 \mathrm{~nm} / 700 \mathrm{~nm}\left(\alpha_{\mathrm{a}, \mathrm{s}(550-700)}\right)$, $450 \mathrm{~nm} / 700 \mathrm{~nm}\left(\alpha_{\mathrm{a}, \mathrm{s}(450-700)}\right)$ and for the three wavelengths $450 \mathrm{~nm} / 550 \mathrm{~nm} / 700 \mathrm{~nm}$ $\left(\alpha_{\mathrm{a}, \mathrm{s}(450-550-700)}\right)$. For both cases, scattering and absorption, the Ångström exponents are higher for the pair of wavelengths $450 \mathrm{~nm} / 550 \mathrm{~nm}$ and smaller values for the pair

$10450 \mathrm{~nm} / 700 \mathrm{~nm}$, defining in this way the shape of the scattering and absorption spectra: decreases quickly on the $450 \mathrm{~nm} / 550 \mathrm{~nm}$ range and decreases less abruptly on the $550 \mathrm{~nm} / 700 \mathrm{~nm}$. For all the Ångström exponents calculated, we determined the fit error, $e$, and the quality of the fit through the $R$ parameter. Both, $e$ and $R$ were used to evaluate and clean the data set.

15 Figure $6 \mathrm{a}$ presents the relation between the scattering and the absorption coefficients. This represents another way to analyze the single scattering albedo parameter. In Fig. $6 \mathrm{~b}$ the relation between the Ångström exponents is also presented and two regions can be identified as showing a higher density of data. Region 1, with higher exponents due to fine particles may be from continental urban sources. And region 2, with lower exponents due to coarse particles, clean and less absorbent, may be from marine origin. These two regions represent the two modes that we could already see in the frequency histogram of the $\alpha_{\mathrm{s}}$ parameter, Fig. 4b. Note the higher density around $\alpha_{\mathrm{s}}=0.7$ and $\alpha_{\mathrm{s}}=1.9$ but the lower density around $\alpha_{\mathrm{s}}=1.3$.

Figure 7 displays the $\omega_{0}$ as a function of the scattering/absorption coefficients and 25 the Ångström exponents. For a given $\sigma_{\mathrm{a}}$ value, the lower $\omega_{0}$ values correspond to smaller particles and higher $\omega_{0}$ values correspond to larger particles (Clarke et al., 2007). Also, the fine particles are present in the more absorbent region while the coarse particles appear as less absorbent. In addition, the particle size can be indicated through the scattering Ångström exponent, with higher $\alpha_{\mathrm{s}}$ for smaller particles 
and smaller $\alpha_{\mathrm{s}}$ for larger particles. In this way, the relationship between $\omega_{0}$, as an intensive aerosol optical property and the $\sigma_{\mathrm{a}}$, as an extensive property, can be used to differentiate background aerosol and inputs of primary aerosols (Cappa et al., 2009). For the ALOMAR station, we observe the predominant high values of $\omega_{0}$, due to very

5 low $\sigma_{\mathrm{a}}$ values. This fact, together with the $\alpha_{\mathrm{s}}$ values registered, allow us to describe the local as extremely clean and only episodically influenced by small particles resulting from long range transport.

In Fig. 7e the single scattering albedo, $\omega_{0}$, is plotted versus its own exponent, $\alpha_{\omega_{0}}$. The spectral shape decreases mainly with the wavelength, $\alpha_{\omega_{0}}>0$, but some cases 10 were registered for which the single scattering albedo increased with the wavelength $\left(\alpha_{\omega_{0}}<0\right)$ due to the arrival of dust.

\section{Conclusions}

Aerosol optical properties relevant to direct climate forcing were investigated during 2008 summer at the ALOMAR station, located in Andøya island, on the Atlantic coast 15 of Norway about $300 \mathrm{~km}$ north of the Arctic Circle. Primary measurements were light absorption by particle soot absorption photometry and light scattering by nephelometry. The scattering coefficients presented strong variability, ranging from 0.254 to $23.209 \mathrm{Mm}^{-1}$ at $550 \mathrm{~nm}$, while the absorption coefficients remain more stable, ranging from 0.130 to $2.281 \mathrm{Mm}^{-1}$ also at $550 \mathrm{~nm}$. The mean absorption coefficient was

20 found to be very weak, leading to higher single scattering albedos (mean $\omega_{0}=0.912$ at $550 \mathrm{~nm})$.

The scattering and absorption Ångström exponents, both present the same behavior, with higher values in the $450-550 \mathrm{~nm}$ range of the spectrum and smaller values in the range from 550 to $700 \mathrm{~nm}$. Yet, the absorption Ångström exponents registered were considerably smaller than the scattering Ångström exponents.

We calculated the single scattering albedo and obtained values ranging from 0.622 to 0.985 at $550 \mathrm{~nm}$. The spectral dependence of the single scattering albedo was also 2171

analyzed. The spectral shape decreases mainly with the wavelength. However, some cases were noted for which the single scattering albedo increased with the wavelength.

Acknowledgements. The ALOMAR eARI (Enhanced Access to Research Infrastructure) Projects, under the EUs 5th framework program (FP), funded the aerosol measurements at 5 Andenes. We thank ALOMAR team for their help and dedication and the INTA team for providing and operate part of the instrumentation. Also, we thank the Division of Atmospheric Sciences (Helsinky University) team headed by Kulmala and its responsible for POLARCAT activities, Laakso, for calibration facilities.

Financial supports from the Spanish MICIIN (projects CGL2008-05939-CO3-00/CLI and 10 CGL200909740) and from the GR-220 Project of the Junta de Castilla y León are gratefully acknowledged.

\section{References}

Aaltonen, V., Lihavainen, H., Kerminen, V.-M., Komppula, M., Hatakka, J., Eneroth, K., Kulmala, M., and Viisanen, Y.: Measurements of optical properties of atmospheric aerosols in 15 Northern Finland, Atmos. Chem. Phys., 6, 1155-1164, doi:10.5194/acp-6-1155-2006, 2006. 2168,2169

Anderson, T. and Ogren, J.: Determining aerosol radiative properties using the TSI 3563 integrating nephelometer, Aerosol Sci. Tech., 29, 57-69, 1998. 2166

Anderson, T., Covert, D., Marshall, S., Laucks, M., Charlson, R., Waggoner, A., Ogren, J., Caldow, R., Holm, R., Quant, F., Sem, G., Wiedensohler, A., Ahlquist, N., and Bates, T.: Performance characteristics of a high-sensitivity, three-wavelength, total scatter/backscatter nephelometer, J. Atmos. Ocean. Tech., 13, 967-986, 1996. 2166

Bond, T.: Spectral dependence of visible light absorption by carbonaceous particles emitted from coal combustion, Geophys. Res. Lett., 28, 4075-4078, 2001. 2164

25 Bond, T., Anderson, T., and Campbell, D.: Calibration and intercomparison of filter-based measurements of visible light absorption by aerosols, Aerosol Sci. Tech., 30, 582-600, 1999. 2166

Boucher, O. and Haywood, J.: On summing the components of radiative forcing of climate change, Clim. Dynam., 18, 297-302, 2001. 2163 
Cappa, C., Bates, T., Quinn, P., and Lack, D.: Source characterization from ambient measurements of aerosol optical properties, Geophys. Res. Lett., 36, L14813, doi:10.1029/ 2009GL038979, 2009. 2171

Clarke, A. and Noone, J.: Measurements of soot aerosol in Arctic snow, Atmos. Environ., 19, 2045-2054, 1985. 2163

Clarke, A., McNaughton, C., Kapustin, V., Shinozuka, Y., Howell, S., Dibb, J., Zhou, J., Anderson, B., Brekhovskikh, V., Turner, H., and Pinkerton, M.: Biomass burning and pollution aerosol over North America: Organic components and their influence on spectral optical properties and humidification response, J. Geophys. Res., 112, D12S18, doi: 10.1029/2006JD007777, 2007. 2170

Delene, D. and Ogren, J.: Variability of aerosol optical properties at four North American surface monitoring sites, J. Aerosol Sci., 59, 1135-1150, 2002. 2168

Dubovik, O., Holben, B., Eck, T., Smirnov, A., Kaufman, Y., King, M., Tanré, D., and Slutsker, I.: Variability of absorption and optical properties of key aerosol types observed in worldwide locations, J. Atmos. Sci., 59, 590-608, 2002. 2164

IPCC: Climate Change 2007, Tech. rep., Intergovernamental Panel on Climate Change, 2007. 2163

Kokhanovsky, A.: Aerosol optics: light absorption and scattering by particles in the atmosphere, Springer, Praxis, 2008. 2163

20 Law, K. and Stohl, A.: Arctic Air Pollution: Origins and Impacts, Science, 315, 1537-1540, doi:10.1126/science.1137695, 2007. 2163

Li, Z., Xia, X., Cribb, M., Mi, W., Holben, B., Wang, P., Chen, H., Tsay, S.-C., Eck, T., Zhao, F., Dutton, E., and Dickerson, R.: Aerosol optical properties and their radiative effects in northern China, J. Geophys. Res., 112, D22S01, doi:10.1029/2006JD007382, 2007. 2163

25 Lin, C., Baker, M., and Charlson, R.: Absorption coefficient of atmospheric aerosol: a method of measurement, Appl. Optics, 12, 1356-1363, 1973. 2166

Quinn, P., Shaw, G., Andrews, E., Dutton, E., Ruoho-Airola, T., and Gong, S.: Arctic haze: current trends and knowledge gaps, Tellus, 59, 99-114, 2007. 2168

Ramanathan, V., Crutzen, P., Kiehl, J., and Rosenfeld, D.: Aerosols, climate, and the hydrological cycle, Science, 294, 2119-2124, doi:10.1126/science.1064034, 2001. 2163

Rodríguez, E.: Caracterización de los aerosoles en la estación sub-ártica de ALOMAR $\left(69^{\circ} \mathrm{N}\right.$, $\left.16^{\circ} \mathrm{E}\right)$ mediante el análisis de propiedades ópticas, Ph.D. thesis, University of Valladolid, 2009 (in Spanish). 2169

2173

Rosen, H., Hansen, D., Gundel, L., and Novakov, T.: Identification of the graphitic carbon component of source and ambient particulates by Raman spectroscopy and an optical attenuation technique, in: Carbonaceous particles in the atmosphere, Lawrence Berkeley Laboratory, 229-232, 1979. 2164

5 Skatteboe, R.: ALOMAR: atmospheric science using lidars, radars and ground based instruments, J. Atmos. Terr. Phys., 58, 1823-1826, doi:10.1016/0021-9169(95)00173-5, 1996. 2165

Toledano, C., Cachorro, V., Berjón, A., Sorribas, M., Vergaz, R., de Frutos, A., Antón, M., and Gausa, M.: Aerosol optical depth at ALOMAR Observatory (Andøya, Norway) in summer 2002 and 2003, Tellus, 58B, 218-228, 2006. 2163, 2165

Tomasi, C., Vitale, V., Lupi, A., Carmine, C. D., Campanelli, M., Herber, A., Treffeisen, R., Stone, R., Andrews, E., Sharma, S., Radionov, V., von Hoyningen-Huene, W., Stebel, K., Hansen, G., Myhre, C., Aaltonen, C. W. V., Lihavainen, H., Hillamo, A. V. R., Ström, J., Toledano, C., Cachorro, V., Ortiz, P., de Frutos, A., Blindheim, S., Frioud, M., Gausa, M., Zielinski,

15 T., Petelski, T., and Yamanouchi, T.: Aerosols in polar regions: A historical overview based on optical depth and in situ observations, J. Geophys. Res., 112, D16205, doi:10.1029/ 2007JD008432, 2007. 2168, 2169

Virkkula, A., Ahquist, N., Covert, D., Arnott, W., Sheridan, P., Quinn, P., and Coffman, D.: Modification, calibration and a field test of an instrument for measuring light absorption by particles, Aerosol Sci. Tech., 39, 68-83, 2005. 2166

Vrekoussis, M., Liakakou, E., Koçak, M., Kubilay, N., Oikonomou, K., Sciare, J., and Mihalopoulos, N.: Seasonal variability of optical properties of aerosols in the Eastern Mediterranean, Atmos. Environ., 39, 7083-7094, doi:10.1016/j.atmosenv.2005.08.011, 2005. 2169 
Table 1. Evaluation of the overall ranges and median values of the absorption/scattering coefficients, the Ångström exponents and the single scattering albedo obtained from the data set measured at ALOMAR.

\begin{tabular}{lcccrc}
\hline & & mean & StD & range & median \\
\hline & $450 \mathrm{~nm}$ & 7.309 & 4.794 & $0.289-31.236$ & 6.576 \\
$\sigma_{\mathrm{s}}\left[\mathrm{Mm}^{-1}\right]$ & $550 \mathrm{~nm}$ & 5.412 & 3.545 & $0.254-23.209$ & 4.753 \\
& $700 \mathrm{~nm}$ & 4.083 & 2.841 & $0.193-18.950$ & 3.392 \\
$\alpha_{\mathrm{s}(450-750)}$ & & 1.368 & 0.613 & $0.196-3.069$ & 1.363 \\
\hline & $450 \mathrm{~nm}$ & 0.448 & 0.329 & $0.135-2.715$ & 0.347 \\
$\sigma_{\mathrm{a}}\left[\mathrm{Mm}^{-1}\right]$ & $550 \mathrm{~nm}$ & 0.400 & 0.273 & $0.130-2.281$ & 0.322 \\
& $700 \mathrm{~nm}$ & 0.358 & 0.226 & $0.119-1.917$ & 0.296 \\
$\alpha_{\mathrm{a}(450-750)}$ & & 0.403 & 0.205 & $0.008-0.969$ & 0.394 \\
\hline & $450 \mathrm{~nm}$ & 0.928 & 0.041 & $0.601-0.986$ & 0.938 \\
$\omega_{0}$ & $550 \mathrm{~nm}$ & 0.913 & 0.047 & $0.622-0.985$ & 0.923 \\
& $700 \mathrm{~nm}$ & 0.893 & 0.062 & $0.496-0.986$ & 0.904 \\
$\alpha_{\omega_{0}(450-750)}$ & & 0.091 & 0.088 & $-0.112-0.949$ & 0.071 \\
\hline
\end{tabular}

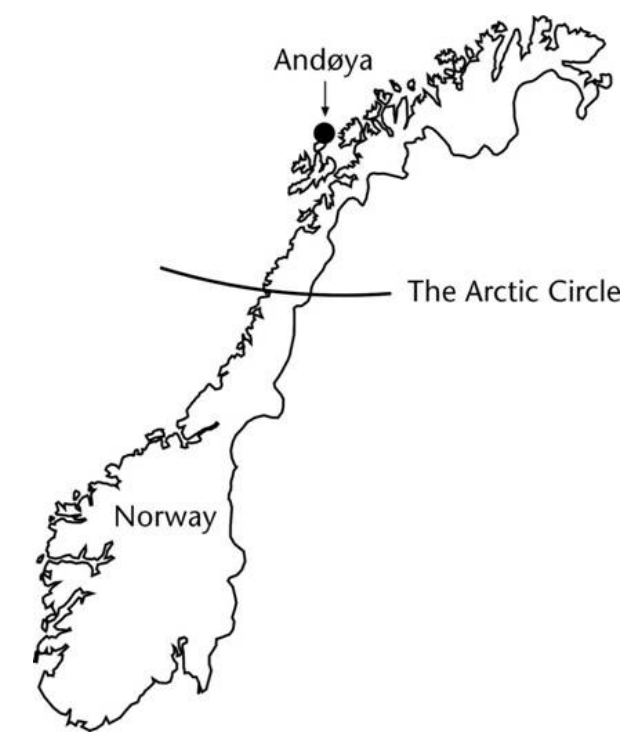

Fig. 1. Location of the ALOMAR station in Northern Norway. 


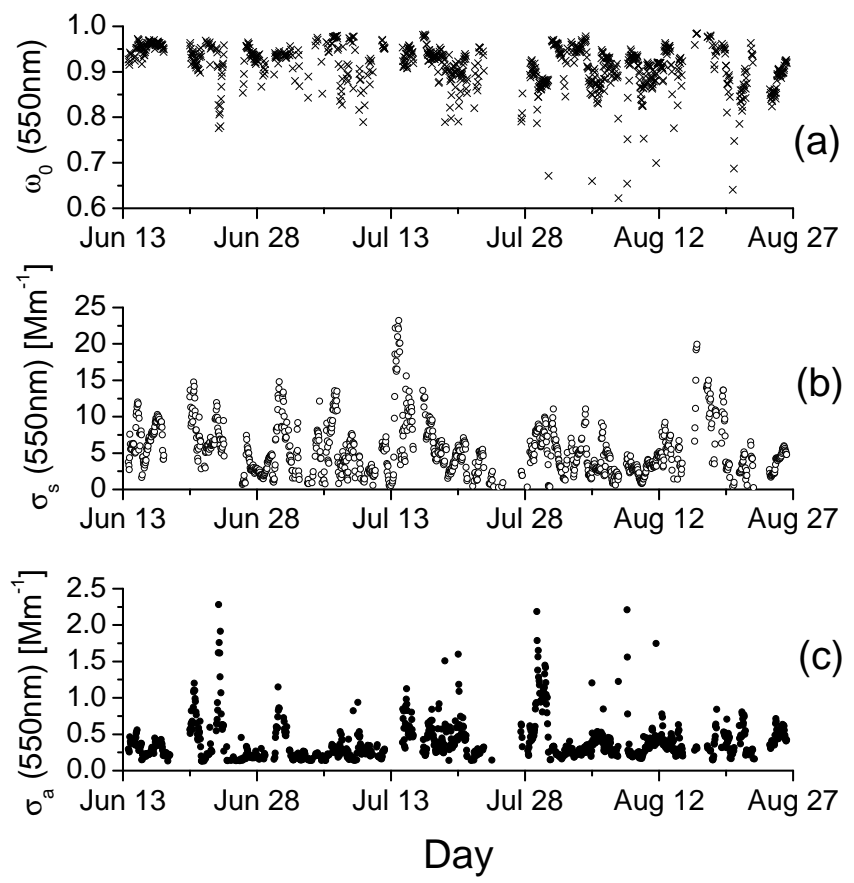

Fig. 2. Time-series of hourly average values of (a) single scattering albedo, (b) scattering coefficient and (c) absorption coefficient at $550 \mathrm{~nm}$.
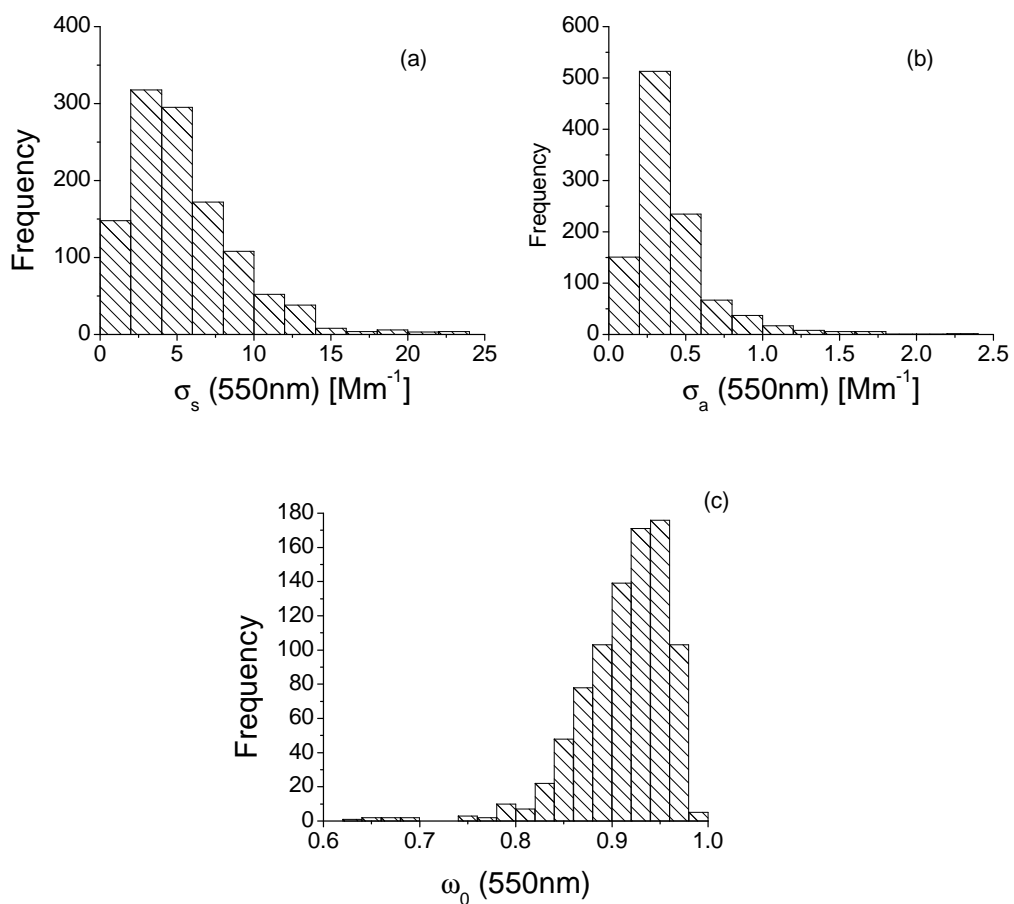

Fig. 3. Frequency histogram for the (a) scattering coefficient, (b) absorption coefficient and (c) single scattering albedo. 

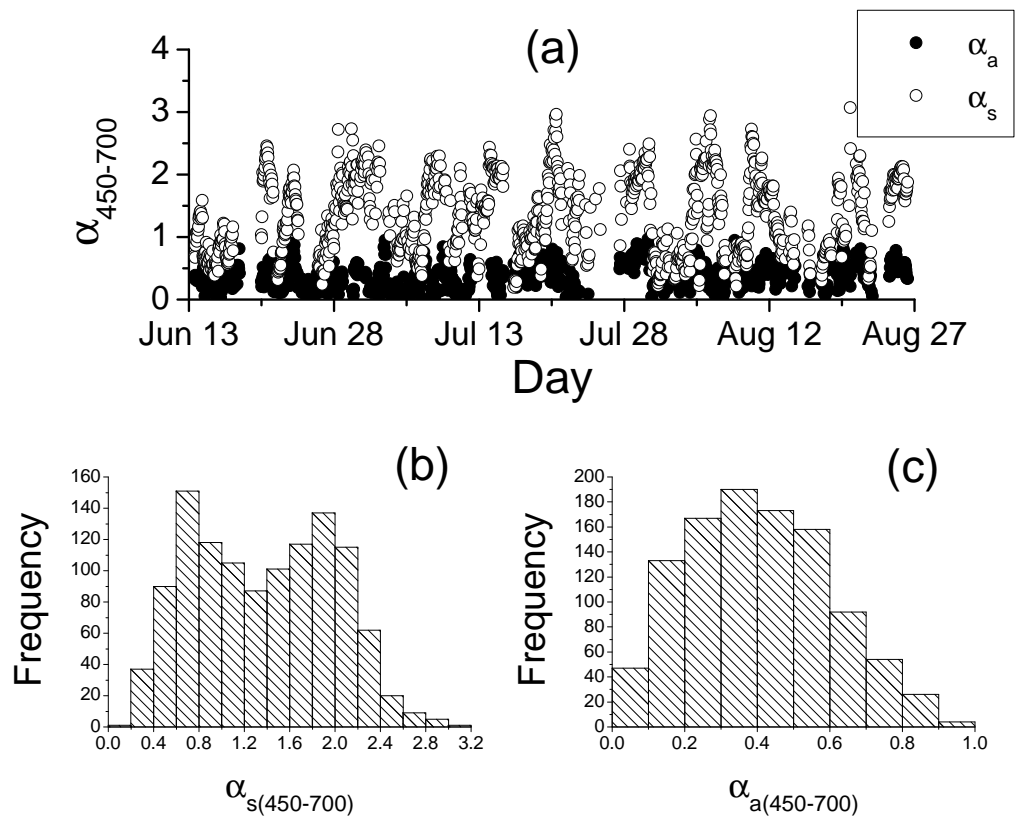

Fig. 4. (a) Time-series of hourly average values of the absorption/scattering Ångström exponents. (b, c) Frequency histogram for the scattering and absorption Ångström exponents.
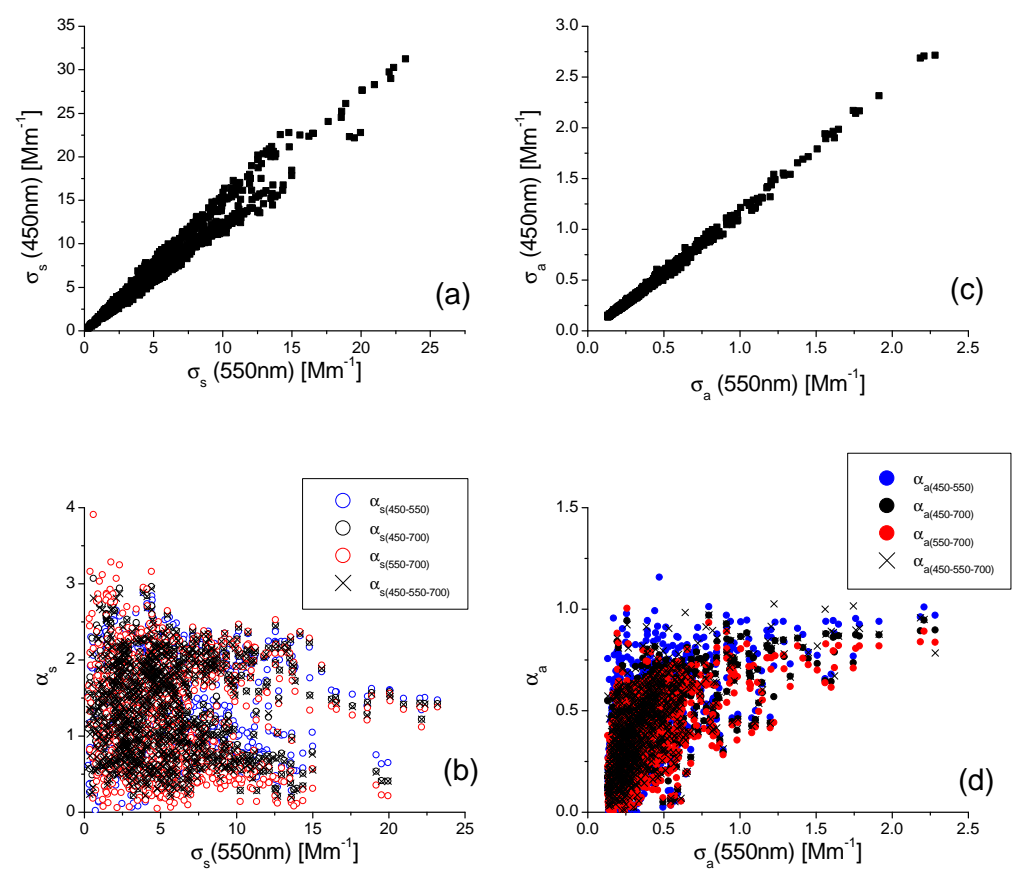

Fig. 5. Hourly average values of the (a) scattering and (c) absorption for different wavelengths. Hourly average values of the (b) scattering coefficient at $550 \mathrm{~nm}$ as a function of the scattering Ångström exponents and (d) absorption coefficient at $550 \mathrm{~nm}$ as a function of the absorption Ångström exponents. 

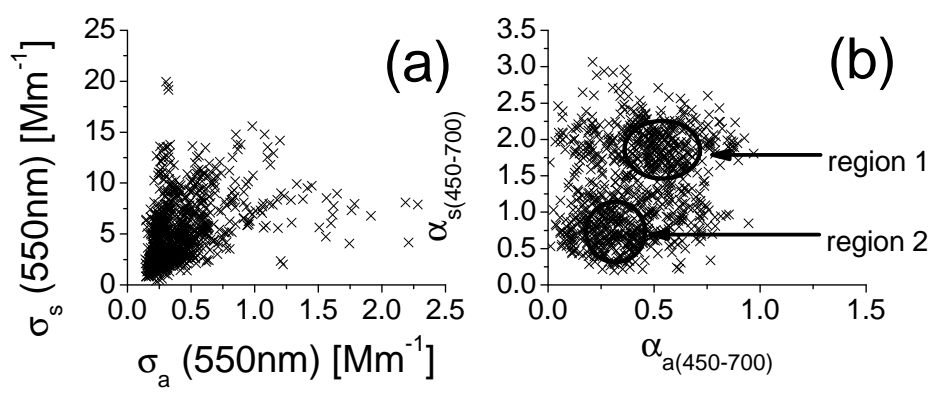

Fig. 6. Relationship between (a) the coefficients $\sigma_{\mathrm{s}}$ and $\sigma_{\mathrm{a}}$, (b) the slopes $\alpha_{\mathrm{s}}$ and $\alpha_{\mathrm{a}}$ and (C) the single scattering albedo, $\omega_{0}$, and its slope, $\alpha_{\omega_{0}}$.
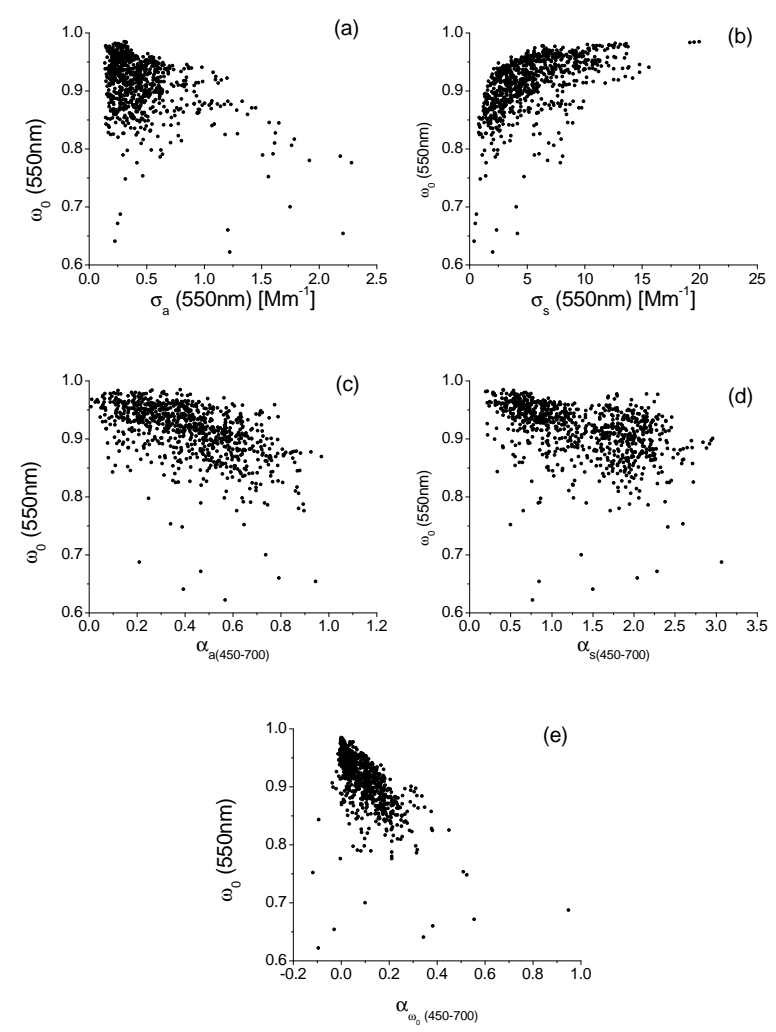

Fig. 7. Hourly average values of the single scattering albedo as a function of the (a) absorption coefficient, (b) scattering coefficient, (c) absorption Ångström exponent, (d) scattering Ångström exponent and (e) exponent $\alpha_{\omega_{0}}$. 